ORIGINAL ARTICLE

\title{
Detection of genomic imbalances by array based comparative genomic hybridisation in fetuses with multiple malformations
}

\author{
C Le Caignec, M Boceno, P Saugier-Veber, S Jacquemont, M Joubert, A David, T Frebourg, \\ J M Rival
}

See end of article for authors' affiliations

....................

Correspondence to: Dr Cédric Le Caignec, Service de Génétique Médicale, Institut de Biologie, Centre Hospitalier Universitaire, 9, quai Moncousu, 44093 Nantes Cedex, France; lecaignec@hotmail.com

Revised version received 18 August 2004 Accepted for publication 1 September 2004

\begin{abstract}
Background: Malformations are a major cause of morbidity and mortality in full term infants and genomic imbalances are a significant component of their aetiology. However, the causes of defects in many patients with multiple congenital malformations remain unexplained despite thorough clinical examination and laboratory investigations.

Methods: We used a commercially available array based comparative genomic hybridisation method (array $\mathrm{CGH}$ ), able to screen all subtelomeric regions, main microdeletion syndromes, and 201 other regions covering the genome, to detect submicroscopic chromosomal imbalances in 49 fetuses with three or more significant anomalies and normal karyotype.

Results: Array CGH identified eight genomic rearrangements (16.3\%), all confirmed by quantitative multiplex PCR of short fluorescent fragments. Subtelomeric and interstitial deletions, submicroscopic duplications, and a complex genomic imbalance were identified. In four de novo cases (15qtel deletion, 16q23.1-q23.3 deletion, 22q11.2 deletion, and mosaicism for a rearranged chromosome 18), the genomic imbalance identified clearly underlay the pathological phenotype. In one case, the relationship between the genotype and phenotype was unclear, since a subtelomeric $6 q$ deletion was detected in a mother and her two fetuses bearing multiple malformations. In three cases, a subtelomeric 10q duplication, probably a genomic polymorphism, was identified.

Conclusions: The detection of 5/49 causative chromosomal imbalances (or $4 / 49$ if the 6qtel deletion is not considered as causative) suggests wide genome screening when standard chromosome analysis is normal and confirms that array CGH will have a major impact on pre and postnatal diagnosis as well as providing information for more accurate genetic counselling.
\end{abstract}

$\Lambda$ potentially lethal or handicapping major defect occurs in $2-3 \%$ of liveborn infants. ${ }^{1}$ Congenital malformations have become the main cause of infant mortality during the first years of life $(21 \%)^{2}$ and are associated with long term morbidity. ${ }^{3}$ Determination of the genetic aetiology of these defects is essential to ensure proper genetic counselling. Approximately 10-15\% of stillborn and liveborn infants with malformations have chromosomal imbalances. ${ }^{45}$ However, the causes of the defects in up to half the patients with multiple congenital malformations remain unexplained despite thorough clinical examination and laboratory investigations. ${ }^{6}$ Therefore, novel genome-wide routine screening procedures need to be developed.

Multiplex fluorescent in situ hybridisation (FISH) painting and spectrum karyotyping, useful for clarifying chromosomal rearrangements, are unable to detect deletions or intrachromosomal duplications. ${ }^{7}$ Submicroscopic rearrangements can be identified using a complete set of subtelomeric probes, ${ }^{8-10}$ but this method is limited by the number of chromosomal loci that can be screened in a single reaction and requires high quality metaphase spreads. Genome-wide screening for chromosomal imbalances using microsatellite markers ${ }^{11} 12$ or high resolution comparative genomic hybridisation $(\mathrm{CGH})^{13}{ }^{14}$ has been reported. These methods, however, are labour intensive and are unsuitable for high resolution screening of the whole genome in a diagnostic setting. ${ }^{15}$

Array based comparative genomic hybridisation (array CGH) derives from a conventional metaphase CGH procedure. ${ }^{16}$ Patient and reference genomic DNAs labelled with two different fluorochromes are co-hybridised to an array of mapped DNA fragments immobilised on slides. ${ }^{17-19}$ The genomic resolution depends on the physical distance between two clones and the sizes of individual clones. Array CGH is a promising high throughput method delivering a high level of resolution and direct mapping of aberrations to the genome sequence. It has been successfully used to detect somatic or germline chromosomal/genomic rearrangements. ${ }^{20-26}$ Recently, array CGH has been developed to identify subtelomeric or submicroscopic rearrangements in patients with idiopathic mental retardation ${ }^{27-30}$ or in spontaneous miscarriages. ${ }^{31}$

In the present study, we used a commercially available array CGH (Vysis/Abbott, IL, USA) to detect chromosomal imbalances in 49 fetuses with three or more significant anomalies of unknown aetiology. This is a first generation array CGH which only contains 287 clones unevenly distributed on the genome. In this original approach, detection and confirmation of the abnormalities was carried out using DNA extracted from fetal frozen tissue. The detection of several chromosomal imbalances argues for the use of genome-wide screening when standard chromosome analysis is normal.

Abbreviations: AS, Angelman syndrome; $\mathrm{CGH}$, comparative genomic hybridisation; CV, coefficient of variation; DGS, DiGeorge syndrome; MDLS, Miller-Dieker lissencephaly; PWS, Prader-Willi syndrome; QMPSF, quantitative multiplex PCR of short fluorescent fragments; WBS, Williams-Beuren syndrome; WHS, Wolf-Hirschhorn syndrome 


\section{METHODS \\ Patients}

Fetuses were chosen from medically terminated pregnancies $(n=41)$ and pregnancies which had ended in spontaneous fetal death $(\mathrm{n}=8)$ at the Centre Hospitalo-Universitaire in Nantes, France. All fetuses presented at least three anomalies in the cardiovascular, urogenital, skeletal, digestive, or central nervous systems. A group of 35 fetuses exhibited a pattern of anomalies suggestive of an early defect in morphogenesis: cerebral midline defects $(n=10)$, defects in the determination of laterality $(n=13)$, abdominal and/or thoracic wall defects $(n=6)$, and malformative association or sequence $(n=6)$. In the other group of 14 fetuses, nonrandom or random associated structural defects non-suggestive of a specific morphogenesis alteration were classified as malformative syndrome $(\mathrm{n}=2)$ or multiple congenital anomalies $(n=12)$. Fetopathological examination and fresh frozen tissue were available for all fetuses. Prenatal $\mathrm{R}$ banding chromosome analysis (at a minimum of ISCN 400 band level) was normal for all 49 fetuses.

Four additional patients with FISH verified known cryptic aberrations (one case with Wolf-Hirschhorn syndrome (WHS; MIM 194190), one case with cri-du-chat syndrome (MIM 123450), one case with subtelomeric 6p deletion, and one case with subtelomeric unbalanced translocation (monosomy $8 \mathrm{p}$ and trisomy $4 \mathrm{p}$ )) were used to examine the reliability of the array CGH system.

\section{Genomic DNA}

Genomic DNA was extracted from frozen fetal lung tissue samples using the phenol:chloroform standard protocol. ${ }^{32}$ Genomic parental DNA was extracted from blood samples using a Nucleon BACC2 kit (Amersham Biosciences, Buckinghamshire, UK) according to the manufacturer's protocol. The DNA concentration was determined by fluorometer using PicoGreen dsDNA quantitation reagent (Molecular Probes, OR, USA) and adjusted to $25 \mathrm{ng} / \mu \mathrm{l}$ for labelling.

\section{Array based comparative genomic hybridisation}

We used a commercially available genomic human Pl, BAC, and PAC array (GenoSensor Array 300, Vysis/Abbott) on which were 287 DNA clones, each clone being represented by three spots. Microdeletions causing DiGeorge (22q11.2) (DGS; MIM 188400), Williams-Beuren (7q11.2) (WBS; MIM 194050), Prader-Willi (PWS; MIM 176270), and Angelman syndromes (15q12) (AS; MIM 105830), MillerDieker lissencephaly (MDLS; MIM 247200), WAGR syndrome (MIM 194072), and WHS (4pl6.3) (WHS; MIM 194190), all 41 human subtelomeric chromosome regions, and 201 additional selected loci, important in cytogenetic and oncology, representing each chromosome arm were spotted on the array (www.vysis.com/ GenoSensorArray300_6615.asp?bhcp =1). Nine $X$ and two Y chromosome specific clones were used as internal controls. Genomic DNA from fetus and reference samples of the opposite sex was labelled by random priming (Microarray Random Priming Kit, Vysis/Abbott) with Cy3-dUTP (test) and Cy5-dUTP (reference) fluorophores (PerkinElmer Life Sciences, MA, USA) and hybridised to the array according to the manufacturer's protocol. Slides were incubated at $37^{\circ} \mathrm{C}$ for 60-72 h, scanned on a GenoSensor Reader scanner (Vysis/ Abbott), and analysed using Genosensor Reader software (version 2.0) (Vysis/Abbott). For each clone, a hybridisation ratio was obtained using the fluorescent intensity from the test and the reference. A p value was calculated for each fluorescent intensity ratio (taking into account the three ratios obtained for each triplicate clone). Clones with a $\mathrm{p}$ value exceeding 0.001 were not investigated. Positive clones were defined by a hybridisation ratio above 1.2 for gain and below 0.8 for loss in relative copy number with $\mathrm{p}<0.001$. Potential chromosomal imbalances were represented by either isolated or clustered positive clones.

\section{Quantitative multiplex PCR of short fluorescent fragments (QMPSF) validation experiments}

To validate our array CGH results, we used QMPSF, a method based on simultaneous amplification of short sequences under quantitative conditions. ${ }^{33-36}$ All potential chromosomal imbalances, defined previously, were confirmed by a quantitative PCR method (QMPSF) except those represented by an isolated clone positive in more than one fetus.

\section{FISH validation experiments}

FISH validation experiments were performed on metaphase spreads prepared from blood samples, amniotic fluid, or chorionic villus samples. The clones were selected using a human clone mapping database (www.ensembl.org) and were obtained from the Wellcome Trust Sanger Institute (Cambridge, UK), the Institute of Molecular Medicine (John Radcliffe Hospital, Oxford, UK), and from a commercial source (Invitrogen, Carlsbad, CA, USA). Genomic target DNA of all clones used for FISH validation was isolated from $200 \mathrm{ml}$ bacterial cultures using QIAgen Plasmid Midi Kits (QIAgen, Hilden, Germany) according to the manufacturer's instructions. Probes were labelled by nick translation with nucleotides conjugated with the green fluorescent dye SpectrumGreen dUTP and the orange fluorescent dye SpectrumOrange dUTP (Vysis/Abbott) according to the manufacturers' suggested protocols. Hybridisation was performed essentially as described elsewhere. ${ }^{37}$ Mapping positions of all clones were confirmed by FISH on normal metaphase spreads. Signals were examined with an Axioplan 2 fluorescence microscope (Carl Zeiss) with appropriate filters and processed by MacProbe v4.3 (PSI, Chester, UK).

\section{RESULTS}

The reliability of the microarray was tested in a blinded fashion using four patients with known FISH confirmed submicroscopic rearrangements. Comparison of the array CGH results with the original diagnoses showed a perfect match in all four patients (data not shown).

For the majority of arrayed clones obtained from the 49 fetuses, limited variation in fluorescence intensity ratios, all within the normal range $(0.8-1.2)$, was observed. The array analyses detected different types of potential genomic imbalances: nine isolated positive clones, two clusters of two positive clones, and three different clusters of positive clones (ranging from three to seven). Using QMPSF, we successfully confirmed chromosomal abnormalities in seven fetuses with clustered positive clones and in one fetus with an isolated positive clone (fig 1; table 1). In addition, eight isolated clones were found to be positive in more than one fetus and therefore QMPSF confirmation was not performed (table 2).

False negative results were identified. Four clones on the $X$ chromosome used as internal controls did not show the expected ratio gain $(>1.2)$ when a female sample was hybridised against a male reference, or loss $(<0.8)$ when a male sample was hybridised against a female reference (table 2). For three slides, one clone on the X chromosome (RP11-607K23) was missing.

The chromosomal imbalances which could be confirmed in eight fetuses (table 1) included three duplications, four deletions, and one complex genomic imbalance. In three fetuses (fetuses 20, 24, 36) the same subtelomeric 10q duplication (clones 137, 138) was detected. In four cases, the 
Table 1 Summary of chromosome abnormalities detected by array CGH and associated positive clones, QMPSF amplicons and FISH probes used for validation experiments, and parental analysis

\begin{tabular}{|c|c|c|c|c|c|c|}
\hline Case & Chromosome abnormality & Estimated size (Mb) & CGH array clones & QMPSF amplicons* & FISH probes & Parental analysis \\
\hline Fetus 17 & Deletion $22 q 11.2$ & 3 & $\begin{array}{l}\text { RP1-157 E19 } \\
\text { RP1-238 C15 } \\
\text { RP11-316 L10 }\end{array}$ & TBX1 & NA & Normal \\
\hline Fetus 21 & Deletion 15qtel & $3-10$ & $\begin{array}{l}\text { GS-251P4 } \\
\text { CTD-2353 N21 } \\
\text { RP1-154 P1 }\end{array}$ & $\begin{array}{l}\text { BLP2 } \\
\text { FU25005 }\end{array}$ & RP1-154 P1 & Normal \\
\hline Fetus 27 & Deletion 6qtel & $<5$ & RP1-57 H24 & $\begin{array}{l}\text { TBP } \\
\text { DLL1 }\end{array}$ & NA & $\begin{array}{l}\text { Maternal } \\
\text { deletion }\end{array}$ \\
\hline Fetus 41 & Deletion 16q23.1-q23.3 & $5-10$ & $\begin{array}{l}\text { RP6-200 H22 } \\
\text { RP1 1-43 L5 }\end{array}$ & $\begin{array}{l}\text { CDH13 } \\
\text { WWOX }\end{array}$ & NA & Normal \\
\hline Fetus 52 & Duplication $18 q$ & $\begin{array}{l}60 \\
\text { (length of } \\
18 q \text { arm) }\end{array}$ & $\begin{array}{l}\text { RP1 1-666O22† } \\
\text { RP1 1-673 D22 } \\
\text { GS-185O2† } \\
\text { GS-568A 15 } \\
\text { GS-385 N22 } \\
\text { RP1 1-676 O1 } \\
\text { RP1 1-507 P3 }\end{array}$ & $\begin{array}{l}\text { KIAA0863 } \\
\text { PARD6G }\end{array}$ & RP1 1-507P3 & Normal \\
\hline Fetus 20 & Duplication 10qtel & $<1$ & $\begin{array}{l}\text { CTD-2545 L18 } \\
\text { GS1-261 B16 }\end{array}$ & $\begin{array}{l}\text { CYP2E } \\
\text { Loc93426 }\end{array}$ & NA & $\begin{array}{l}\text { Maternal } \\
\text { duplication }\end{array}$ \\
\hline Fetus 24 & Duplication 10qtel & $<1$ & $\begin{array}{l}\text { CTD-2545 L18 } \\
\text { GS1-261 B16 }\end{array}$ & $\begin{array}{l}\text { CYP2E } \\
\text { Loc93426 }\end{array}$ & NA & $\begin{array}{l}\text { Paternal } \\
\text { duplication }\end{array}$ \\
\hline Fetus 36 & Duplication 10qtel & $<1$ & $\begin{array}{l}\text { CTD-2545 L18 } \\
\text { GS1-261 B16 }\end{array}$ & $\begin{array}{l}\text { CYP2E } \\
\text { Loc93426 }\end{array}$ & NA & $\begin{array}{l}\text { Maternal } \\
\text { duplication }\end{array}$ \\
\hline
\end{tabular}

NA, not available. Mb, megabases.

*All these abnormalities detected by array CGH were confirmed by QMPSF with one or two amplicons; †clones showing weak signals.

abnormality was de novo and in four was inherited from a phenotypically normal parent.

Fetopathological examination of fetus 17 at 23.5 weeks gestation showed bilateral renal agenesis, type B interrupted aortic arch, thymic hypoplasia, agenesis of the uterus oviducts, and proximal portion of the vagina. Microdeletion $22 \mathrm{ql} 1.2$ was suspected but could not be confirmed, as no cells were available for FISH analysis. Deletion of three clustered probes (RP1-157E19, RP1-238C15, and RP11-316L10) located at 22q11.2 was detected by array CGH. This submicroscopic abnormality was confirmed by QMPSF (TBXI amplicon). As FISH analysis confirmed that neither parent had this deletion, it was considered a de novo mutation.

Table 2 Isolated positive clones identified by array CGH in more than one fetus and left unconfirmed and false negative clones

\begin{tabular}{|c|c|c|c|}
\hline & $\begin{array}{l}\text { Vysis/Abbott } \\
\text { target } \\
\text { reference }\end{array}$ & $\begin{array}{l}\text { Clone library } \\
\text { reference }\end{array}$ & Case \\
\hline \multirow{8}{*}{$\begin{array}{l}\text { Isolated positive } \\
\text { clones left } \\
\text { unconfirmed }\end{array}$} & 3 & GS1-254B24 & 35,42 \\
\hline & 17 & RP4-791M13 & 9,10 \\
\hline & 27 & $\mathrm{RP} 11-436 \mathrm{~K} 12$ & $\begin{array}{l}5,6,7,9,10,13, \\
19,22,42,43 \\
49\end{array}$ \\
\hline & 91 & GS1 246M20 & $13,35,49$ \\
\hline & 110 & MYC $^{*}$ & 9,10 \\
\hline & 141 & GS1-137C7 & $8,12,19,61$ \\
\hline & 179 & RP1 1-47P23 & $6,7,22,28$ \\
\hline & 218 & RP1 1-5809 & 46,58 \\
\hline \multirow[t]{4}{*}{$\begin{array}{l}\text { False negative } \\
\text { clones }\end{array}$} & 278 & RP4-677N1 & $\begin{array}{l}2,20,21,23,29, \\
46\end{array}$ \\
\hline & 280 & RP3-453A3 & $\begin{array}{l}1,2,12,13,17 \\
21,22,23,46 \\
47,48\end{array}$ \\
\hline & 281 & RP3-323B6 & $\begin{array}{l}1,2,6,13,17 \\
18,20,21,22 \\
23,25,35,38 \\
40,42,43,46 \\
48,52\end{array}$ \\
\hline & 283 & PAC-92 E23 & $1,8,41$ \\
\hline
\end{tabular}

Autopsy of fetus 21 at 22.5 weeks gestation showed intrauterine growth retardation $(<5$ th percentile), a double outlet right ventricle associated with mitral valve hypoplasia, bilateral multicystic kidneys, and hypoplastic bifid uterus. Asplenia, median liver, and common mesentery were suggestive of abdominal situs ambiguus (dextro-isomerism type). Deletion of three subtelomeric 15q clustered clones (GS-251P4, CTD-2353N21, and RP1-154P1) including the $I G F 1 R$ gene was detected by array CGH. This submicroscopic abnormality was confirmed using QMPSF (BLP2 and FLJ25005 amplicons) and FISH on metaphase spreads from a prenatal sample (RP1-154Pl probe) (fig 2A). Parental karyotypes and FISH analyses using an RP1-154Pl subtelomeric probe confirmed that neither parent had this deletion and excluded a balanced translocation. The deletion was considered a de novo mutation.

Autopsy of fetus 27 at 20.5 weeks gestation revealed left diaphragmatic hernia, neopontocerebellar hypoplasia, bilateral talipes equinovarus, and bilateral brachymesophalangy. Another pregnancy was terminated 2 years later due to suspicion on echograph of malformative cerebral recurrence. Fetopathological examination at 30 weeks gestation showed neopontocerebellar hypoplasia and triventricular hydrocephaly without any other abnormalities. This second fetus was not included in the 49 fetuses because inclusion criteria were not met (third malformation missing). In both fetuses, a subtelomeric 6q deletion (RP1-57H24 clone) was detected by array CGH and confirmed by QMPSF (TBP and DLLl amplicons). Unfortunately, no material was available from the fetuses for additional FISH validation. A similar deletion was observed by FISH (RP1-57H24 probe) in the mother who presented learning disabilities, no facial anomaly, and normal karyotype (fig 2B). Karyotype and FISH analyses were normal for the father.

Autopsy of fetus 41 showed pulmonic atresia, auriculoventricular canal, polysplenia, bilateral multicystic kidneys, enlarged bladder, thin abdominal wall, facial dysmorphia including short nose, thin lips, wide mouth and low inserted ears, and unique umbilical artery. Array CGH showed interstitial 16q deletion with two clustered probes (RP6$200 \mathrm{H} 22$ located in 16q23.2 and RP11-43L5 in 16q24.2-q24.3). These results were confirmed by QMPSF (CHD13 and WWOX 
Fetus 17 deletion $22 q 11.2$

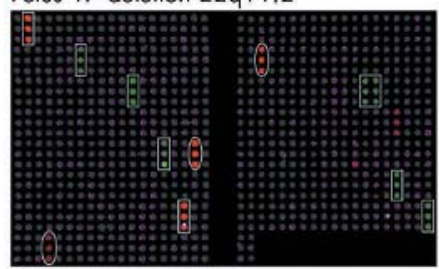

Fetus 21 deletion 15qtel
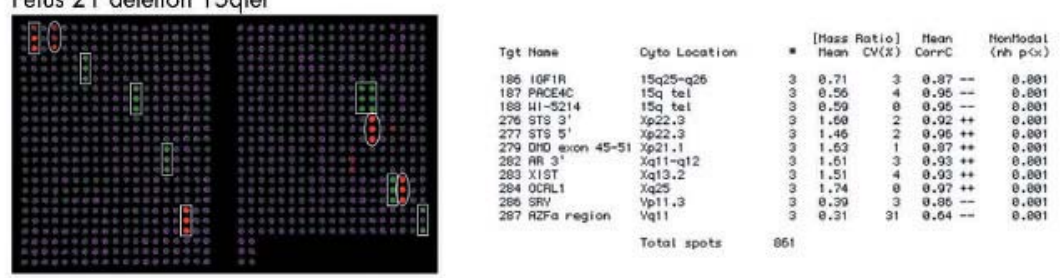

Fetus 27 deletion 6qtel
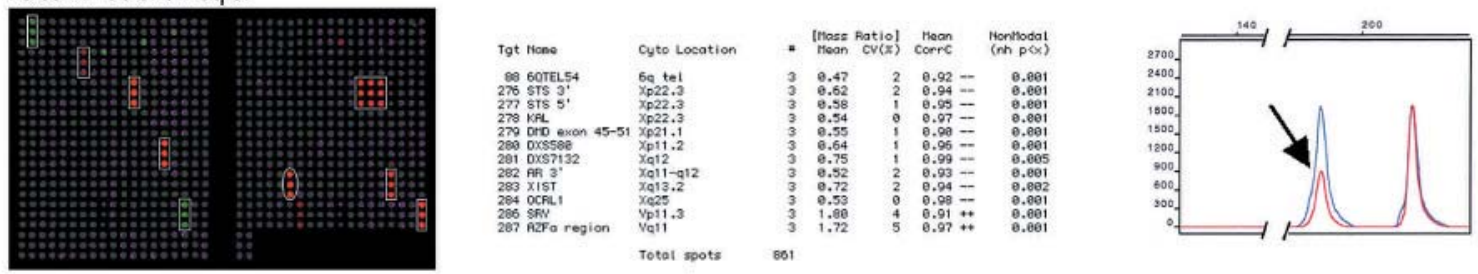

Fetus 41 deletion 16q23.1->q23.3
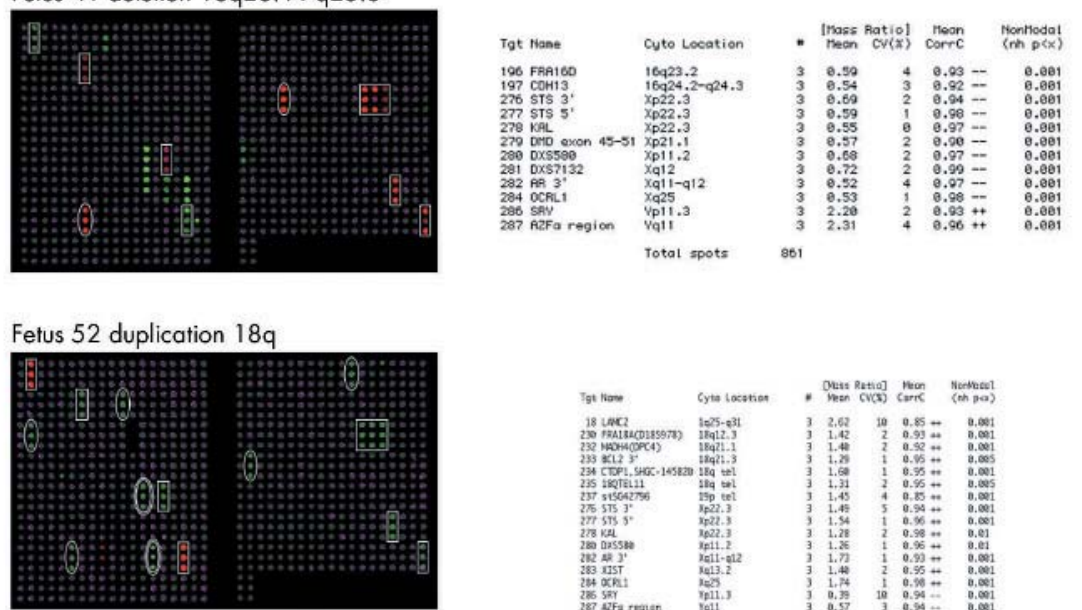

Fetus 20 duplication 10 qtel
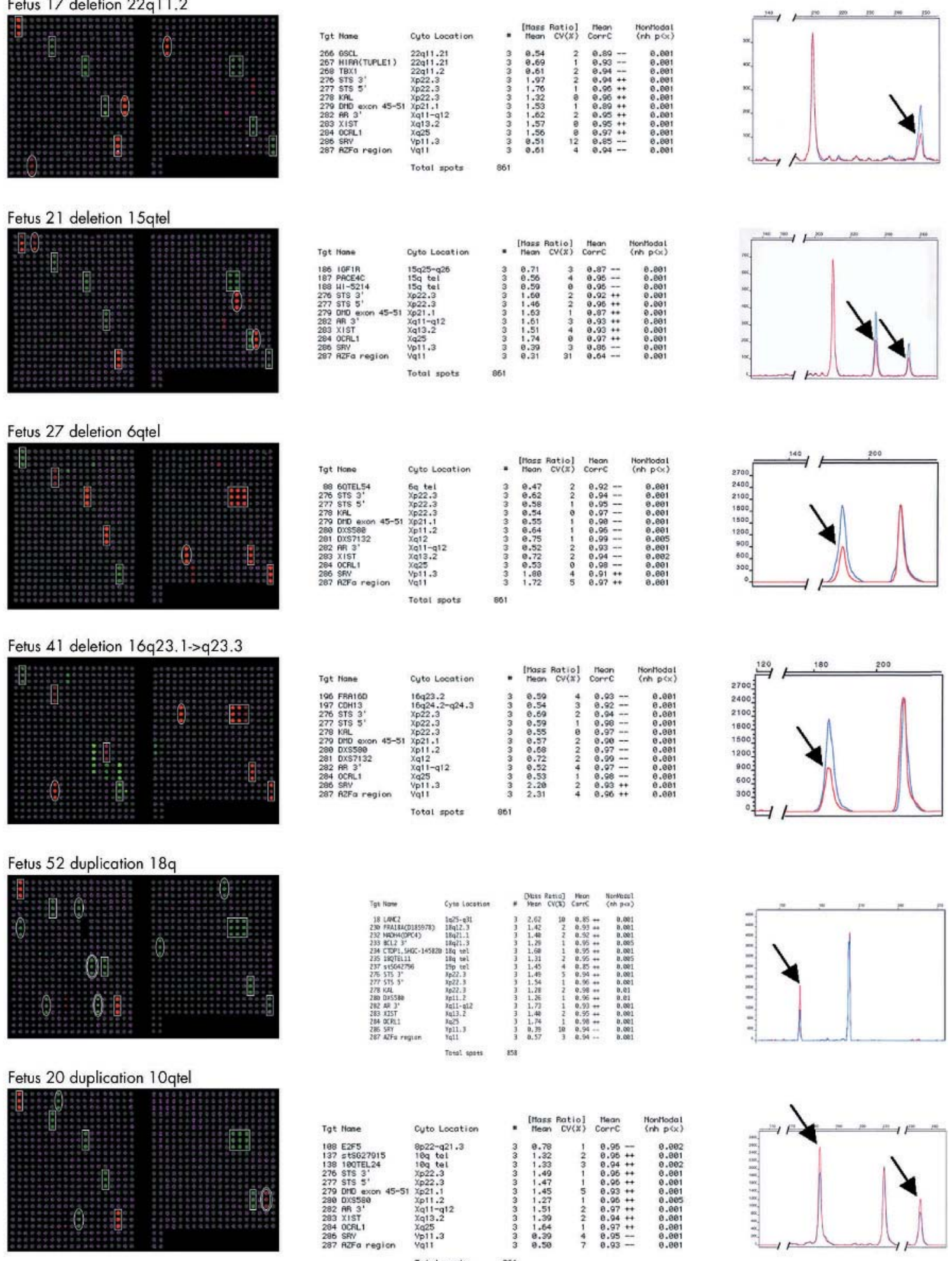

Figure 1 (A) Processed images of array CGH for the six different types of abnormalities using array CGH with 287 genomic targets (Vysis/Abbott). Grey spots represent normal spots, non-circled red or green spots represent internal controls, circled red spots represent QMPSF confirmed deletion, and circled green spots represent QMPSF confirmed duplication. Doubled circled spots represent false positive spots. (B) Abbreviated reports from the GenoSensor Reader system listing all the targets that have significantly non-modal ratios with $p<0.001$ in addition to targets of borderline significance $(0.002<\mathrm{p}<0.01)$. The three left hand columns identify the target. Next is the number of replicate spots (always three), then the normalised mean ratio for the target and the coefficient of variation (CV) of the ratios of replicate spots. The next column contains an indicator if the target has a normalised mean ratio $>1.2$ or $<0.8$ (without consideration of its $C V$ ). The final column contains the $p$ value, reflecting both the difference of a mean target ratio from 1.0, and its CV. For four experiments, the total number of clones is 861 (287 targets in triplicate) meaning that no clones have been excluded. For one experiment, the total number of clones is 858, as one clone is missing (RP1 1-607K23). (C) Confirmation of array CGH results using QMPSF. In each panel, the electropherogram of the fetus (in red) was superimposed on that of a control (in blue). The vertical axis displays fluorescence in arbitrary units and the horizontal axis indicates the size in base pairs. Heterozygous deletions or duplications can easily be detected by a $50 \%$ reduction or amplification, respectively, of the corresponding peak height (indicated by an arrow). The tables and graphs in this figure are available in a larger format from http://jmg.bmijournals.com/supplemental. 
amplicons). Unfortunately, no patient material was available for additional FISH validation. Cytogenetic and FISH analyses using RP6-200H22 and RP11 probes revealed both parents were normal, indicating a de novo deletion.

Autopsy of fetus 52 at 13 weeks gestation showed occipitocervical rachischisis with meningoencephalocele, palatine cleft, right aortic arch, and left diaphragmatic aplasia. Array CGH showed 18q duplication with five probes (RP11-673D22, GS-568A15, GS-385N22, RP11-676O1, and RP11-507P3). Two clones (RP11-666O22, GS-185O2) located in 18q showed weak signals. Subtelomeric 18q duplication was confirmed by QMPSF (KIAA0863 and PARD6G amplicons). Subtelomeric $18 p$ deletion was excluded by QMPSF (USP14 amplicon). Following these results, all metaphase spreads from prenatal samples were re-analysed. A total of 20 metaphases from short term chorionic villus culture were normal. A rearranged chromosome 18 was identified in two of 12 metaphases from long term culture. FISH using 18p (GS-74G18) and $18 \mathrm{q}$ (RP11-507P3) subtelomeric and specific 18 centromeric probes was performed on metaphase spreads and 100 interphase chorionic villus cell nuclei (fig $2 \mathrm{C}$ and $\mathrm{D}$ ). The presence of a rearranged chromosome 18 was confirmed in metaphases and 21 of 100 cell nuclei with a unique centromere and subtelomeric 18q signals at both ends of arms, leading to a diagnosis of an isochromosome 18q. A subtelomeric $18 \mathrm{p}$ deletion was identified on the other 79 of the 100 cell nuclei. The karyotype from chorionic villus is therefore 46,XX/46,XX, del(18)(ptel)/46,XX,-18, +i(18q). Cytogenetic and FISH analysis using GS-74G18 and RPll507P3 probes showed both parents were normal, indicating a de novo rearrangement.

Fetuses 20, 24, and 36 presented the same chromosomal imbalance. Autopsy of fetus 20 who was stillborn at 26 weeks gestation showed type III oesophageal atresia, unilateral renal agenesis, and polysplenia. Autopsy of fetus 24 at
33 weeks gestation showed association of anal atresia, urogenital sinus, hydrometrocolpos, and bilateral dysplastic kidneys referred to as cloacal dysgenesis. Common mesentery, gallbladder agenesis, and sacrum defect were also noted. Autopsy of fetus 36 at 23 weeks gestation showed omphalocele, transposition of great vessels, ventricular septal defect, olfactive tractus agenesis, and abnormal angulation of sacrum.

A subtelomeric 10q duplication was identified in all three cases by array CGH (CTD-254L18 and GS1-261Bl6 clones) and confirmed by QMPSF. Duplications were inherited in all three cases.

\section{DISCUSSION}

In this study, we applied array CGH methods to detect novel submicroscopic abnormalities in a diagnostic setting. This array is able to screen all human subtelomeric regions, microdeletion syndromes, and 201 other regions covering the genome in a single hybridisation assay. We investigated 49 fetuses with multiple malformations and normal karyotype. Array CGH identified different potential abnormalities. All eight abnormalities, which met criteria described in the Methods section, were confirmed by QMPSF. Subtelomeric and interstitial deletions, submicroscopic duplications, and a complex genomic imbalance were identified.

In four de novo cases (fetuses 17, 21, 41, 52), the genomic imbalance identified clearly underlies the pathological phenotype.

To our knowledge, bilateral renal agenesis, identified in fetus 17, has never been reported in 22q11.2 microdeletion syndrome. Agenesis of uterus, oviducts, and proximal part of the vagina associated with unilateral renal agenesis, and contralateral multicystic renal dysplasia have been described once. $^{38}$ These two cases indicate that the wide clinical
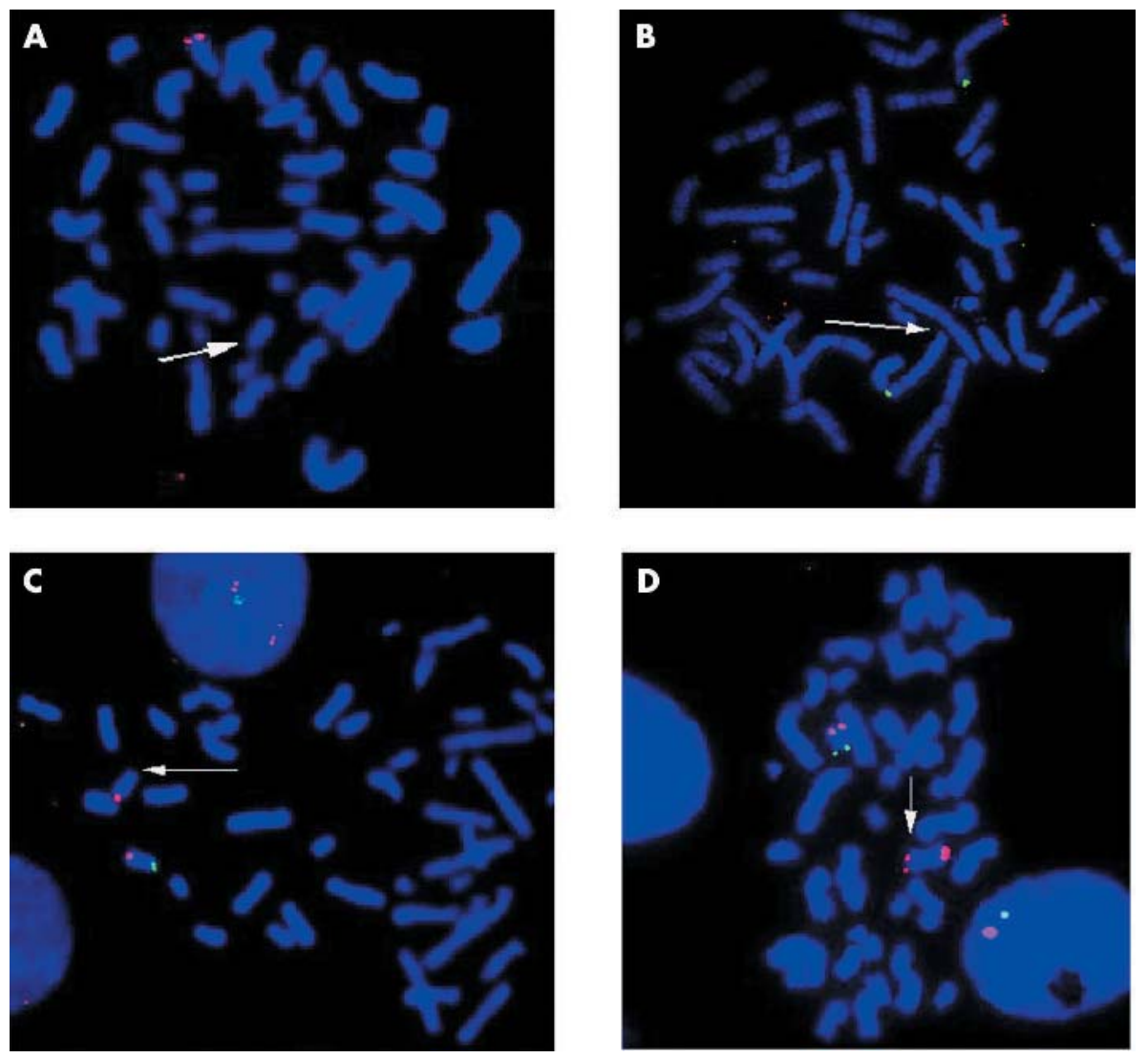

Figure 2 (A) FISH performed on metaphase spreads of fetus 21 with a subtelomeric 15q (RP1-154P1) probe showing a signal (orange) on the normal chromosome 15, but absence of a signal on the deleted chromosome 15 (arrow). (B) FISH performed on metaphase spreads of the mother of fetus 27 with subtelomeric 6p (GS1$19615)$ and $6 q$ (RP1-57H24) probes showing normal $6 p$ signals (green) on both chromosomes 6, a normal 6q signal (orange) on the normal chromosome 6 , but absence of a $6 q$ signal on the deleted chromosome 6 (arrow). (C) FISH performed on metaphase spreads of fetus 52 with subtelomeric 18p (GS-74G18) and 18q (RP1 1-507P3) probes showing normal $18 q$ signals (orange) on both chromosomes 18, a normal 18p signal (green) on the normal chromosome 18, but absence of a 18p signal on the deleted chromosome 18 (arrow). (D) FISH performed on metaphase spreads of fetus 52 with subtelomeric $18 p$ (green) and 18q (orange) probes showing normal signals on the normal chromosome 18, but 18q signals (orange) at both ends of the isochromosome 18 (arrow). 
spectrum of the 22q11.2 microdeletion includes renal and genital anomalies.

Terminal de novo 15q26.1 deletion (without ring formation), identified in fetus 21 , is rare. Subtelomeric $15 \mathrm{q}$ deletion using subtelomeric screening has never been described before. ${ }^{10}{ }^{39-40}$ The deletion we report is $3-10 \mathrm{Mb}$ in size and includes the insulin-like growth factor receptor gene (IGFIR) which plays an important role in cell growth control and cardiovascular development. ${ }^{4142}$ Loss of the IGFIR gene, located in the 15q26.3 region, is likely responsible for growth retardation and complex heart defects. The case we report includes some symptoms previously described for the 15q26qtel deletion, ${ }^{43}$ but also genital and situs anomalies. These results suggest that a gene involved in laterality may be located in this chromosomal region.

De novo interstitial 16q deletions, as identified in fetus 41 , are rare. The deletion we report is a minimum size of $5 \mathrm{Mb}$ and encompasses bands 16q23.1 to 16q23.3. The absence of a visible deletion on the re-analysed karyotype and the low density of clones located in $16 \mathrm{q}$ on the array prevent this deletion being further refined. All 16q interstitial deletions previously reported were identified through conventional cytogenetic analyses ${ }^{44-47}$ The clinical presentation reported in those cases included severe as well as normal phenotypes. $16 \mathrm{q} 21$ deletions have been reported with a normal phenotype but not, to our knowledge, 16q23 deletions. It therefore seems reasonable to conclude that this deletion is causal. Detection of small interstitial deletions through high density array CGH will facilitate genotype-phenotype correlations.

Fetus 52 is an example of discordant chromosomal mosaicism as the subtelomeric $18 p$ deletion was only identified in trophoblastic mesenchymal cells and not in fetal tissues. However, this fetus, in addition to trisomy $18 \mathrm{q}$ malformations, ${ }^{48}$ exhibits cerebral midline defect, more suggestive of $18 \mathrm{p}$ monosomy. ${ }^{49}$ Our inability to detect the mosaic subtelomeric $18 \mathrm{p}$ deletion in fetal lung may be due to the limits of the array CGH and QMPSF sensitivity, but also may be related to an $18 \mathrm{p}$ deletion confined to another tissue.

In one case (fetus 27), a subtelomeric 6q deletion was detected in a mother and her two fetuses bearing multiple malformations. Therefore, the relationship between the genotype and the phenotype is unclear. However, the subtelomeric 6q clone (RPl-57H24), frequently used for diagnostic purposes, is not described as polymorphic. ${ }^{9}$ We also screened 120 patients with mental retardation and did not detect any deletions. In addition, diaphragmatic hernia (exhibited by fetus 27) has been described in one patient with terminal $6 \mathrm{q}$ deletion. ${ }^{50}$ Several hypotheses can be suggested including incomplete penetrance or variable expressivity of the rearrangement in the mother and the two affected fetuses (such as 22q11.2 microdeletion syndrome), chromosomal region submitted to parental imprinting, a recessive disorder with allele mutation in the second parent, an increase in size of the deletion in the fetuses, or a co-incidental finding.

In three cases (fetuses 20, 24, 36), a subtelomeric 10q duplication was identified. The anomaly was inherited in all cases. The recurrence of this altered profile in three fetuses exhibiting different phenotypes argues in favour of a polymorphism. Recently, two studies have reported the same subtelomeric duplication, which seems to be a common familial variant. ${ }^{3151}$ Segmental duplications provide substrates for homologous recombination and consequently a high rate of rearrangement, which may be associated with clinical features. ${ }^{52}$

We detected eight isolated positive clones scattered throughout the genome (table 2). As these clones were identified in 2-11 fetuses, we assumed that they did not cause pathological phenotypes. Moreover, we were not able to distinguish between genomic polymorphisms and falsepositive results in the absence of QMPSF validation. In a previous study, Vissers et al ${ }^{28}$ investigated 20 patients with mental retardation using an array CGH of $1 \mathrm{Mb}$ resolution and found an average of seven false-positive clones $(0.21 \%)$. Schoumans et al $l^{53}$ using the same technology applied to 10 previously identified cases containing 16 cryptic chromosome aberrations, did not report any false-positive results, which may be due to restrictive thresholds. Schaeffer $e t$ al ${ }^{31}$ using GenoSensor array 300 in a series of 41 miscarriages reported only one subtelomeric $10 \mathrm{q}$ duplication which is likely a genomic polymorphism. The detection of such rearrangements by these new high resolution technologies reveals new interpretation problems and consequently genetic counselling issues. This underlines the need for systematic analysis of genomic polymorphisms in normal controls in order to understand the pathological role of such rearrangements.

A total of 13 clones showing abnormal fluorescence intensity ratios $(<0.8$ or $>1.2)$ at a lower level of significance $(0.002<\mathrm{p}<0.01)$ were also identified. These clones, considered as negative, may also represent true genomic imbalances that have been missed. This in turn suggests that our criteria for QMPSF validation were highly restrictive. Therefore, the sensitivity of the array CGH could be increased at the cost of lower specificity.

Our study based on array CGH is the first to be applied to the detection of genomic imbalances using frozen tissues from fetuses with three or more significant anomalies. The detection rate of causative chromosomal imbalances in this series of fetuses is $10 \%$ (5/49) or $8 \%$ (4/49) after exclusion of inherited anomalies and polymorphisms. Only one genomewide screening using microsatellite markers has been applied to patients with malformations and led to the identification of 7/120 (5.8\%) rearrangements. ${ }^{15}$ More recently, array CGH with GenoSensor array 300 was conducted on DNA extracted from chorionic villus culture in 41 products of conception. This array detected all cytogenetic abnormalities previously analysed by $\mathrm{G}$ banding and revealed new rearrangements in $4 / 41(9.8 \%)$ cases or in $3 / 41(7.3 \%)$ if we consider that the subtelomeric 10q duplication is, as in our study, a polymorphism. ${ }^{31}$ In two studies of patients with idiopathic mental retardation with the array extended to 3500 clones, the diagnostic yield of rearrangements was $15-20 \%$ after exclusion of inherited anomalies. ${ }^{28}{ }^{30}$ We did not detect any imbalances common to these studies, with the exception of the subtelomeric 10q duplication.

Array CGH is a promising method. First, very small amount of genomic DNA (100 ng) are required to detect submicroscopic rearrangements. Second, it is suitable for prenatal diagnosis for which very few metaphases are available or else are often insufficient for complete investigations (for example, the 22q11.2 deletion in fetus 17 and the mosaic $18 \mathrm{q}$ duplication in fetus 52 were missed by standard cytogenetic analyses). Third, array CGH is useful in spontaneous or induced abortions as the high failure rate of postmortem karyotyping is due to a lack of viable fetal cells for culture (as for trisomy 21 in one fetus not included in this study). However, array CGH is unable to detect balanced translocation, triploidies, or a low level of mosaicism.

The detection of eight genomic imbalances in a series of 49 fetuses with multiple malformations in this study underscores the strength of the array CGH technique. The GenoSensor array 300 can detect microdeletion syndromes and subtelomeric rearrangements, but resolution of the current array is variable with large gaps and some abnormalities can be missed. Therefore, this first generation array cannot be considered a high resolution screening method. A second generation array with a higher resolution is expected to detect more subtle anomalies but is not expected to be 
more labour intensive. A tiling resolution array consisting of 32433 overlapping clones covering the entire human genome is in the process of being constructed.$^{54}$ Array CGH will have a major impact on pre and postnatal diagnoses, genetic counselling, and healthcare. Retrospective analyses are also of psychological comfort for parents experiencing stillbirth or pregnancy loss.

\section{ACKNOWLEDGEMENTS}

We thank Drs Regina Regan and Jonathan Flint (Institute of Molecular Medicine, John Radcliffe Hospital, Oxford, UK) for providing some of the second generation set of human chromosome specific subtelomere probes and the Sanger Center for supplying BAC probes. We are also grateful to the families who participated in this study and to Morgane Le Foulgoc and Allison Felley for editing the manuscript.

\section{ELECTRONIC-DATABASE INFORMATION}

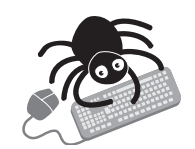

The URLs for data presented herein are as follows: Online Mendelian Inheritance in Man (OMIM), http:// www.ncbi.nlm.nih.gov/Omim/ (for AS, cri-du-chat syndrome, DGS, MDLS, PWS, SMS, WAGR, WBS, and WHS); The Wellcome Trust Sanger Institute, Cambridge, UK, http://www.ensembl.org; and Journal of Medical Genetics Supplementary Material, http://jmg.bmijournals.com/supplemental.

\section{Authors' affiliations}

C Le Caignec, M Boceno, S Jacquemont, A David, J M Rival, Service de Génétique Médicale, Institut de Biologie, Centre Hospitalier Universitaire, Nantes, France

C Le Caignec, Laboratoire d'Etude du Polymorphisme de l'ADN, Faculté de Médecine, Nantes, France

P Saugier-Veber, T Frebourg, Laboratoire de Génétique Moléculaire, Centre Hospitalo-Universitaire, Rouen, France

M Joubert, Service d'Anatomie Pathologique, Centre HospitaloUniversitaire, Nantes, France

This work was supported by a grant from the Direction de la Recherche Clinique du Centre Hospitalier Universitaire de Nantes (PHRC 02/11Q). Conflict of interest: none declared.

\section{REFERENCES}

1 Kalter H, Warkany J. Medical progress. Congenital malformations: etiologic factors and their role in prevention (first of two parts). N Engl J Med 1983:308:424-31

2 Kalter H, Warkany J. Congenital malformations (second of two parts). $N$ Engl J Med 1983;308:491-7.

3 De Galan-Roosen AE, Kuijpers JC, Meershoek AP, van Velzen D. Contribution of congenital malformations to perinatal mortality. A 10 years prospective regional study in The Netherlands. Eur J Obstet Gynecol Reprod Biol 1998;80:55-61.

4 Nelson K, Holmes LB. Malformations due to presumed spontaneous mutations in newborn infants. N Engl J Med 1989;320:19-23.

5 Stevenson RE. The genetic basis of human anomalies. In: Stevenson RE, Hall JG, Goodman RM, eds. Human malformations and related anomalies, Vol 1. New York: Oxford University Press, 1993:115-36.

6 Stevenson RE. Causes of congenital anomalies: an overview and historical perspective. In: Stevenson RE, Hall JG, Goodman RM, eds. Human malformations and related anomalies, Vol 1. New York: Oxford University Press, 1993:3-20.

7 Biesecker LG. The end of the beginning of chromosome ends. Am J Med Genet 2002; 107:263-6.

8 Knight SJ, Regan R, Nicod A, Horsley SW, Kearney L, Homfray T, Winter RM, Bolton $\mathrm{P}$, Flint J. Subtle chromosomal rearrangements in children with unexplained mental retardation. Lancet 1999;354:1676-81.

9 Knight SJ, Lese CM, Precht KS, Kuc J, Ning Y, Lucas S, Regan R, Brenan M, Nicod A, Lawrie NM, Cardy DL, Nguyen H, Hudson TJ, Riethman HC, Ledbetter DH, Flint J. An optimized set of human telomere clones for studying telomere integrity and architecture. Am J Hum Genet 2000;67:320-32.

10 De Vries BB, Winter R, Schinzel A, van Ravenswaaij-Arts C. Telomeres: a diagnosis at the end of the chromosomes. J Med Genet 2003;40:385-98.

11 Slavotinek A, Rosenberg M, Knight S, Gaunt L, Fergusson W, Killoran C, Clayton-Smith J, Kingston H, Campbell RH, Flint J, Donnai D, Biesecker L. Screening for submicroscopic chromosome rearrangements in children with idiopathic mental retardation using microsatellite markers for the chromosome telomeres. J Med Genet 1999;36:405-11.
12 Rosenberg MJ, Vaske D, Killoran CE, Ning Y, Wargowski D, Hudgins L, Tifft CJ, Meck J, Blancato JK, Rosenbaum K, Pauli RM, Weber J, Biesecker LG. Detection of chromosomal aberrations by a whole-genome microsatellite screen. Am J Hum Genet 2000;66:419-27.

13 Kirchhoff $M$, Rose $H$, Lundsteen $C$. High resolution comparative genomic hybridisation in clinical cytogenetics. J Med Genet 2001;38:740-4.

14 Ness GO, Lybaek H, Houge G. Usefulness of high-resolution comparative genomic hybridization (CGH) for detecting and characterizing constitutional chromosome abnormalities. Am J Med Genet 2002;113:125-36.

15 Rosenberg MJ, Killoran C, Dziadzio L, Chang S, Stone DL, Meck J, Aughton D, Bird LM, Bodurtha J, Cassidy SB, Graham JM Jr, Grix A, Guttmacher AE, Hudgins L, Kozma C, Michaelis RC, Pauli R, Peters KF, Rosenbaum KN, Tifft CJ, Wargowski D, Williams MS, Biesecker LG. Scanning for telomeric deletions and duplications and uniparental disomy using genetic markers in 120 children with malformations. Hum Genet 2001; 109:31 1-8.

16 Kallioniemi A, Kallioniemi OP, Sudar D, Rutovitz D, Gray JW, Waldman F, Pinkel D. Comparative genomic hybridization for molecular cytogenetic analysis of solid tumors. Science 1992;258:818-21.

17 Solinas-Toldo S, Lampel S, Stilgenbaver S, Nickolenko J, Benner A, Dohner H, Cremer T, Lichter P. Matrix-based comparative genomic hybridization: biochips to screen for genomic imbalances. Genes Chromosomes Cancer 1997;20:399-407.

18 Pinkel D, Segraves R, Sudar D, Clark S, Poole I, Kowbel D, Collins C, Kuo WL, Chen C, Zhai Y, Dairkee SH, Ljung BM, Gray JW, Albertson DG. High resolution analysis of DNA copy number variation using comparative genomic hybridization to microarrays. Nat Genet 1998;20:207-11.

19 Snijders AM, Nowak N, Segraves R, Blackwood S, Brown N, Conroy J, Hamilton G, Hindle AK, Huey B, Kimura K, Law S, Myambo K, Palmer J, Ylstra B, Yue JP, Gray JW, Jain AN, Pinkel D, Albertson DG. Assembly of microarrays for genome-wide measurement of DNA copy number. Nat Genet 2001;29:263-4.

20 Albertson DG Ylstra B, Segraves R, Collins C, Dairkee SH, Kowbel D, Kuo WL, Gray JW, Pinkel D. Quantitative mapping of amplicon structure by array CGH identifies CYP24 as a candidate oncogene. Nat Genet 2000;25:144-6.

21 Bruder CE, Hirvela C, Tapia-Paez I, Fransson I, Segraves R, Hamilton G, Zhang XX, Evans DG, Wallace AJ, Baser ME, Zucman-Rossi J, Hergersberg M, Boltshauser E, Papi L, Rouleau GA, Poptodorov G, Jordanova A, RaskAndersen H, Kluwe L, Mautner V, Sainio M, Hung G, Mathiesen T, Moller C, Pulst SM, Harder H, Heiberg A, Honda M, Niimura M, Sahlen S, Blennow E, Albertson DG, Pinkel D, Dumanski JP. High resolution deletion analysis of constitutional DNA from neurofibromatosis type 2 (NF2) patients using microarray-CGH. Hum Mol Genet 2001;10:271-82.

22 Buckley PG, Mantripragada KK, Benetkiewicz M, Tapia-Paez I, Diaz De Stahl T, Rosenquist $M$, Ali H, Jarbo C, De Bustos C, Hirvela C, Sinder Wilen B, Fransson I, Thyr C, Johnsson BI, Bruder CE, Menzel U, Hergersberg M, Mandahl N, Blennow E, Wedell A, Beare DM, Collins JE, Dunham I, Albertson D, Pinkel D, Bastian BC, Faruqi AF, Lasken RS, Ichimura K, Collins VP, Dumanski JP. A full-coverage, high-resolution human chromosome 22 genomic microarray for clinical and research applications. Hum Mol Genet 2002;11:3221-9.

23 Wilhelm M, Veltman JA, Olshen AB, Jain AN, Moore DH, Presti JC Jr, Kovacs $G$, Waldman FM. Array-based comparative genomic hybridization for the differential diagnosis of renal cell cancer. Cancer Res 2002;62:957-60

24 Veltman JA, Fridlyand J, Pejavar S, Olshen AB, Korkola JE, DeVries S, Carroll P, Kuo WL, Pinkel D, Albertson D, Cordon-Cardo C, Jain AN, Waldman FM. Array-based comparative genomic hybridization for genomewide screening of DNA copy number in bladder tumors. Cancer Res 2003;63:2872-80.

25 Yu W, Ballif BC, Kashork CD, Heilstedt HA, Howard LA, Cai WW, White LD, Liu W, Beaudet AL, Bejiani BA, Shaw CA, Shaffer LG. Development of a comparative genomic hybridization microarray and demonstration of its utility with 25 well-characterized 1 p36 deletions. Hum Mol Genet 2003;12:2145-52.

26 Locke DP, Segraves R, Nicholls RD, Schwartz S, Pinkel D, Albertson DG Eichler EE. BAC microarray analysis of $15 q 11-q 13$ rearrangements and the impact of segmental duplications. J Med Genet 2004;41:175-82.

27 Veltman JA, Schoenmakers EF, Eussen BH, Janssen I, Merkx G, van Cleef B, van Ravenswaaii CM, Brunner HG, Smeets D, van Kessel AG. Highthroughput analysis of subtelomeric chromosome rearrangements by use of array-based comparative genomic hybridization. Am J Hum Genet 2002;70:1269-76.

28 Vissers LE, de Vries BB, Osoegawa K, Janssen IM, Feuth T, Choy CO, Straatman $H$, van der Vliet W, Huys EH, van Rijk A, Smeets D, van Ravenswaaii-Arts CM, Knoers NV, van der Burgt I, de Jong PJ, Brunner HG, van Kessel AG, Schoenmakers EF, Veltman JA. Array-based comparative genomic hybridization for the genomewide detection of submicroscopic chromosomal abnormalities. Am J Hum Genet 2003;73:1261-70.

29 Harada N, Hatchwell E, Okamoto N, Tsukahara M, Kurosawa K, Kawame H, Kondoh T, Ohashi H, Tsukino R, Kondoh Y, Shimokawa O, Ida T, Nagai T, Fukushima Y, Yoshiura K, Niikawa N, Matsumoto N. Subtelomere specific microarray based comparative genomic hybridisation: a rapid detection system for cryptic rearrangements in idiopathic mental retardation. J Med Genet 2004;41:130-6.

30 Shaw-Smith C, Redon R, Rickman L, Rio M, Willatt L, Fiegler H, Firth H, Sanlaville D, Winter R, Colleaux L, Bobrow M, Carter NP. Microarray based comparative genomic hybridisation (array-CGH) detects submicroscopic chromosomal deletions and duplications in patients with learning disability/ mental retardation and dysmorphic features. J Med Genet 2004;41:241-8.

31 Schaeffer AJ, Chung J, Heretis K, Wong A, Ledbetter DH, Lese Martin C. Comparative genomic hybridization-array analysis enhances the detection of 
aneuploidies and submicroscopic imbalances in spontaneous miscarriages. Am J Hum Genet 2004:74:1 168-74.

32 Sambrook J, Fritsch EF, Maniatis T. Purification of nucleic acids. In: Molecular cloning: a laboratory manual, 2nd ed. Cold Spring Harbor, NY: Cold Spring Harbor Laboratory Press, 1989:appendix E.3.

33 Charbonnier F, Raux G, Wang Q, Drouot N, Cordier F, Limacher JM, Saurin JC, Puisieux A, Olschwang S, Frebourg T. Detection of exon deletions and duplications of the mismatch repair genes in hereditary nonpolyposis colorectal cancer families using multiplex polymerase chain reaction of shor fluorescent fragments. Cancer Res 2000;60:2760-3.

34 Saugier-Veber $\mathbf{P}$, Drouot N, Lefebvre S, Charbonnier F, Vial E, Munnich A, Frebourg T. Detection of heterozygous SMN1 deletions in SMA families using a simple fluorescent multiplex PCR method. J Med Genet 2001;38:240-3.

35 Charbonnier F, Olschwang S, Wang Q, Boisson C, Martin C, Buisine MP Puisieux A, Frebourg T. MSH2 in contrast to MLH1 and MSH6 is frequently inactivated by exonic and promoter rearrangements in hereditary nonpolyposis colorectal cancer. Cancer Res 2002;62:848-53.

36 Jacquet H, Raux G, Thibaut F, Hecketsweiler B, Houy E, Demilly C, Haouzir S Allio G, Fouldrin G, Drouin V, Bou J, Petit M, Campion D, Frebourg T. PRODH mutations and hyperprolinemia in a subset of schizophrenic patients. Hum Mol Genet 2002;11:2243-9.

37 Le Caignec C, Winer N, Boceno M, Delnatte C, Podevin G, Liet JM, Quere MP Joubert $M$, Rival JM. Prenatal diagnosis of sacrococcygeal teratoma with constitutional partial monosomy $7 \mathrm{q} /$ trisomy $2 \mathrm{p}$. Prenat Diagn 2003;23:981-4.

38 Devriendt K, Moerman P, Van Schoubroeck D, Vandenberghe K, Fryns JP. Chromosome 22q1 1 deletion presenting as the Potter sequence. J'Med Genet 1997;34:423-5.

39 Siebler T, Lopaczynski W, Terry CL, Casella SJ, Munson P, De Leon DD, Phang L, Blakemore KJ, McEvoy RC, Kelley RI. Insulin-like growth factor I receptor expression and function in fibroblasts from two patients with deletion of the distal long arm of chromosome 15. J Clin Endocrinol Metab 1995:80:3447-57.

40 Tonnies H, Schulze I, Hennies H, Neumann LM, Keitzer R, Neitzel H. De novo terminal deletion of chromosome 15q26.1 characterised by comparative genomic hybridisation and FISH with locus specific probes. J Med Genet 2001;38:617-21.

41 Liu JP, Baker J, Perkins AS, Robertson EJ, Efstratiadis A. Mice carrying null mutations of the genes encoding insulin-like growth factor I (lgf-1) and type 1 IGF receptor (lgf1r). Cell 1993;75:59-72.
42 Delafontaine $\mathbf{P}$. Insulin-like growth factor I and its binding proteins in the cardiovascular system. Cardiovasc Res 1995;30:825-34.

43 Roback EW, Barakat AJ, Dev VG, Mbikay M, Chretien M, Butler MG. An infant with deletion of the distal long arm of chromosome 15 (q26.1-qter) and loss of insulin-like growth factor 1 receptor gene. Am J Med Genet 1991;38:74-9.

44 McDonald DM, Spinner NB, King MC, Emanuell BS, Zackai EH. Interstitial deletion $16 \mathrm{q}$ in two patients: confirmation of cytogenetics by analysis of haptoglobin levels. Am J Hum Genet 1987;41:A132.

45 Callen DF, Eyre $\mathrm{H}$, Lane S, Shen Y, Hansmann I, Spinner N, Zackai E, McDonald-McGinn D, Schuffenhaver S, Wauters J. High resolution mapping of interstitial long arm deletions of chromosome 16: relationship to phenotype. J Med Genet 1993;30:828-32.

46 Monaghan KG, Van Dyke DL, Wiktor A, Feldman GL. Cytogenetic and clinical findings in a patient with a deletion of 16q23. 1: first report of bilateral cataracts and a 16q deletion, Am J Med Genet 1997;73:180-3.

47 Werner W, Kraft S, Callen DF, Bartsch O, Hinkel GK. A small deletion of 16q23.1 $\rightarrow 16 q 24.2$ [del(16)(q23.1q24.2). ish del(16)(q23.1q24.2)(D16S395+, D16S348-, P5432+)] in a boy with iris coloboma and minor anomalies. Am J Med Genet 1997:70:371-6.

48 Turleau C, de Grouchy J. Trisomy 18qter and trisomy mapping of chromosome 18. Clin Genet 1977;12:361-71.

49 de Grouchy J, Turleau C. Clinical atlas of human chromosomes, 2nd ed. New York: John Wiley, 1984:308-13.

50 Krassikoff N, Sekhon GS. Terminal deletion of $6 \mathrm{q}$ and Fryns syndrome: a microdeletion/syndrome pair? Am J Med Genet 1990;36:363-4.

51 Waggoner D, Eash D, Ilkin Y, Surti U, McPherson E, Siegler M, Tepperberg J, Lese-Martin C. The $10 \mathrm{q}$ telomere region is a common site mediating polymorphic and pathogenic telomere rearrangements. Am J Hum Genet 2003;73:307, A806.

52 Kriek M, White SJ, Bouma MC, Dauwerse HG, Hansson KB, Nijhuis JV, Bakker B, van Ommen GJ, den Dunnen JT, Breuning MH. Genomic imbalances in mental retardation. J Med Genet 2004:41:249-55.

53 Schoumans J, Anderlid BM, Blennow E, Teh BT, Nordenskjold M. The performance of $\mathrm{CGH}$ array for the detection of cryptic constitutional chromosome imbalances. J Med Genet 2004;41:198-202.

54 Ishkanian AS, Malloff CA, Watson SK, DeLeeuw RJ, Chi B, Coe BP, Snijders A, Albertson DG, Pinkel D, Marra MA, Ling V, MacAulay C, Lam WL. A tiling resolution DNA microarray with complete coverage of the human genome. Nat Genet 2004;36:299-303. 